\title{
Plasticity in reproductive timing by crabs in adjacent tidal regimes
}

\author{
Steven G. Morgan * \\ Marine Environmental Sciences Consortium, PO Box 369-370, Dauphin Island, Alabama 36528, USA
}

\begin{abstract}
Tidal variation may cause reproductive timing by fiddler crabs Uca pugilator (Bosc) to vary geographically and seasonally. Fiddler crabs in a semidiurnal tidal regime along the Atlantic coast of the USA were previously shown to release larvae synchronously during maximum amplitude evening high tides near new and full moons throughout the reproductive season. In the present study, fiddler crabs in a diurnal tidal regime on the Gulf coast of the USA released larvae during intermediate amplitude flood tides near dawn regardless of lunar phase throughout most of the reproductive season. Late in the summer, peak larval release occurred near maximum amplitude high tides as on the Atlantic coast. In a mixed semidiurnal tidal regime on the Gulf coast, peak larval release by fiddler crabs occurred during intermediate amplitude high tıdes near dawn, but biweekly periodicity was weak late in the reproductive season. Intraspecific variation in reproductive timing arose because nocturnal maximum high tides did not occur along the Gulf coast during most of the summer, but these tides returned during late summer in the diurnal tidal regime. Reproductive timing changed concomitantly with changing phase relationships of tides with light-dark and lunar cycles. Variation in reproductive timing is phenotypic because crabs that were translocated reciprocally between diurnal and mixed semidiurnal tidal regimes entrained to the timing patterns of local crabs. A hierarchy of rhythms regulating reproductive timing was revealed by the degree to which larval release kept phase with lunar, tidal amplıtude, tidal and light-dark cycles. These hierarchies enabled crabs to track phase shifts of cycles in variable tidal environments and may enhance mean reproductive success throughout the range of the species.
\end{abstract}

KEY WORDS: Larvae Hatching $\cdot$ Rhythms Tides Diel Lunar Predation Crabs

\section{INTRODUCTION}

Activities and physiologies of many coastal marine animals are synchronized with the rise and fall of tides, including locomotion, foraging, courtship, mating, spawning, hatching, larval swimming, settlement, respiration and pigment migration (Palmer 1974, 1990, Gibson 1978, DeCoursey 1983, Morgan 1995 for reviews) Oscillations in tides often are tracked endogenously, thereby enabling organisms to anticipate and reliably time these activities (Palmer 1974, 1990, DeCoursey 1983, Forward 1987, Giese \& Kanatani 1987). Tidal and tidal amplitude rhythms are entrained by cues that are associated with tides, such as

\footnotetext{
- Present address: Marine Sciences Research Center, State University of New York, Stony Brook, New York 11794-5000. USA.E-mail: smorgan@ccmail.sunysb.edu
}

salinity, temperature, hydrostatic pressure, vibrations and moonlight (Palmer 1974, DeCoursey 1983, Forward 1987, Giese \& Kanatani 1987). The tidal cycle refers to the semidaily or daily cycle of high and low tides, and the tidal amplitude cycle is the biweekly cycle of daily differences in the height of high and low tides that is usually synonymous with the springneap cycle. Coastal animals also commonly track changes in the light-dark cycle (Palmer 1974, 1990, DeCaursey 1983, Giese \& Kanatani 1987, Morgan 1995). Thus, circatidal (usually about $12.4 \mathrm{~h}$ but sometimes about $24.8 \mathrm{~h}$ ), circadian (about $24 \mathrm{~h}$ ) and circasemilunar (about 14.8 d) rhythms in reproduction and behavior often are entrained by tidal, light-dark, tidal amplitude and lunar cycles.

The timing of activities may vary along coastlines, because species may range through several tidal environments. The periodicity, phasing and range of 
tides differ geographically (Table 1), which necessarily causes the timing of tidally timed activities to change relative to light-dark and lunar cycles (Barnwell 1976, Neumann 1986, Morgan \& Christy 1994). Along the Atlantic coast of the USA, semidiurnal (2 tidal cycles per day) tides prevail, and the phase relationship between the tides and the light-dark cycle varies with a predictable semilunar period throughout the year Large amplitude tides peak near dusk on new and full moons year round. All along this coast fiddler crabs Uca pugilator (Bosc) release larvae during early evening maximum amplitude high tides near new and full moons throughout the summer (Christy 1982, Salmon et al. 1986, Hovel 1995). Therefore, reproduction by fiddler crabs along this coast may be timed endogenously by as many as 4 environmental cycles (light-dark, tidal, tidal amplitude, lunar) (DeCoursey 1979, 1983, Bergin 1981, Salmon et al. 1986)

Along the northern Gulf of Mexico, mixed semidiurnal (usually 2, but sometimes 1 tidal cycle per day), diurnal (1 tidal cycle per day) mixed diurnal (usually 1. but sometimes 2 tidal cycles per day) tides occur. This tidal variation arises due to the geometry of the Gulf of Mexico and the dominance of the declination of the moon over planetary alignment (synodic 'lunar' cycle) in tidal forcing (Table 1). The dominance of the lunar declination cycle is apparent because maximum amplitude high tides coincide with new and full moons during some months and quarter moons during other months (Fig. 1). During most of the summer in the diurnal tidal regime, maximum amplitude high tides always occur during the afternoon when the moon is over the Tropics of Cancer and Capricorn. When the moon crosses the equator, a second high tide arises early in the morning and tidal amplitudes are minimal. After the moon crosses the equator 1 to 2 d later, the early morning peak becomes dominant. This means that low tide rather than high tide now occurs during late afternoon. Therefore a $12 \mathrm{~h}$ phase shift in the time of high tide occurs and peak high tides always occur in daylight. Late in the summer the situation is reversed and high tides peak during darkness until the following spring

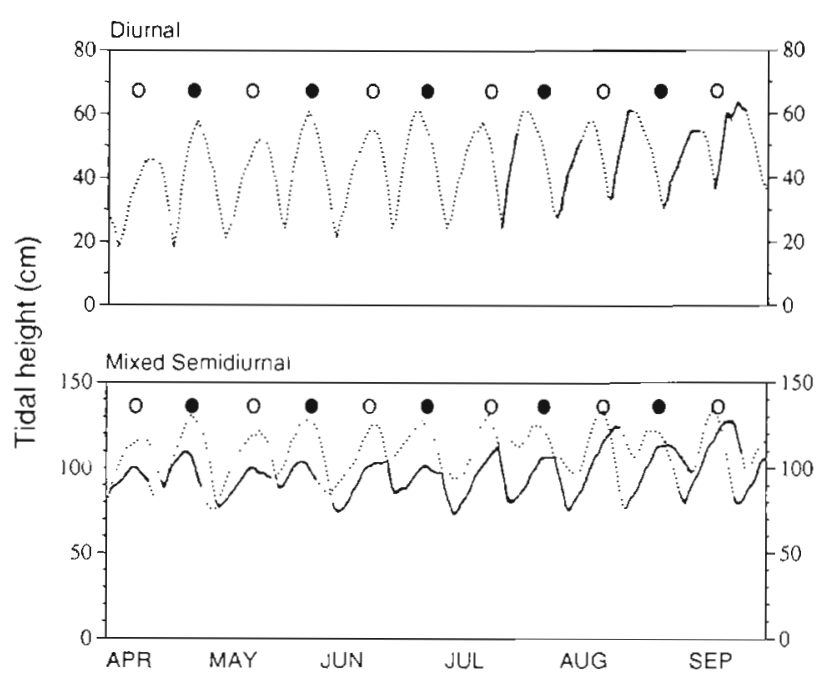

Fig. 1. Daily nocturnal (-) and diurnal (- - -) predicted high tide relative to lunar phase $\bullet$ and 0 represent new and full moons, respectively) in the diurnal and mixed semidiumal tidal regmes at St. Joseph Bay and Florida State Marine Laboratory at Turkey Point in northwestern Florida during 1989. Maximum amplitude high tides occurred during the day in both tidal regimes. Nocturnal high tides prmarily occurred near minimum amplitude tides throughout most of the study period in the diurnal tidal regime, and they occurred during larger amplitude tides in the mixed semidiurnal tidal regime. See Fig. 2 for location of study sites

Reproductive timing by fiddler crabs in the diurnal tidal regime is unknown, but changes in the phasing of the several entraining environmental cycles ensure that larval release will not occur at the same time as in the semidiurnal tidal regime. Because maximum amplitude high tides do not occur at night in this tidal regime throughout most of the reproductive season, reproductive timing by fiddler crabs must change relative to at least one of the entraining environmental cycles. Peak larval release may occur either during (1) maximum amplitude high slack tides in the daytime (light-dark phase shift), (2) minimum amplitude high slack tides before dawn (biweekly phase shift) or (3) intermediate amplitude flood tides near dawn (biweekly and tidal phase shifts). Furthermore if the tidal amplitude cycle entrains biweekly periodicities, then

Table 1. Periodicities of 4 environmental cycles, tidal ranges and dominant forces controlling tides in 3 tidal regimes along the Atlantic and Gulf coasts of the USA (see Barnwell 1976 for review)

\begin{tabular}{|c|c|c|c|c|c|c|}
\hline \multirow[t]{2}{*}{ Tidal regime } & \multirow{2}{*}{ Light-dark (h) } & \multicolumn{3}{|c|}{ - Period of environmental cycles } & \multirow{2}{*}{$\begin{array}{c}\text { Tidal range } \\
\qquad(\mathrm{m})\end{array}$} & \multirow[t]{2}{*}{ Dominant tidal force } \\
\hline & & Tidal cycle (d) & Tidal amplitude (d) & Lunar (d) & & \\
\hline Semidiurnal & 24 & 12.4 & 14.8 & 29.5 & $0.9-3.7$ & Synodic cycle \\
\hline Mixed semidiurnal & 24 & Mostly 12.4 & 13.7 & 27.3 & $0.5-1.0$ & Lunar declination \\
\hline Diurnal & 24 & 24.8 & 13.7 & 27.3 & $0.7-1.0$ & Lunar declination \\
\hline
\end{tabular}


crabs should keep phase with the tidal amplitude rather than the lunar cycle when the 2 cycles are out of phase (Christy 1978, Morgan \& Christy 1994). Seasonal variation in reproductive timing also may arise when nocturnal maximum amplitude high tides return late in the summer. At this time, the phasing of environmental cycles is the same as on the Atlantic coast, and reproductive timing by fiddler crabs on the 2 coasts should be similar.

The mixed semidiurnal tidal environment is similar to that of the adjacent diurnal tidal regime, except that the diurnal inequality in the height and interval between the 2 daily high tides is not sufficiently large to obscure one of the peaks. As in the diurnal tidal environment, maximum amplitude high tides occur in daylight and the largest amplitude nocturnal high tides occur several days away during summer. Fiddler crabs in this tidal regime released larvae near minimum amplitude tides and quarter moons (Christy 1978).

The timing of reproduction by other species of crabs and marine insects has also been associated with changing relationships of tides to light-dark and lunar cycles along coastlines (Neumann 1986, Morgan \& Christy 1994). Marine midges appear to have adapted genetically to local tidal conditions (Neumann 1966), whereas reproductive timing by crabs may be phenotypically plastic (Morgan \& Christy 1994). Reproductive timing within populations of crabs changed temporally in a mixed semidiurnal tidal regime on the Caribbean coast of Panama, where the phasing of entraining environmental cycles changed during the year. A hierarchical arrangement of endogenous rhythms was proposed that show how crabs are able to track complex changes in phase relationships among environmental cycles. Hierarchies of rhythms were revealed by the degree to which larval release remained in phase with each environmental cycle. Species that tracked tides throughout the year, necessarily released larvae at different times of the light-dark and lunar cycles. Conversely, species that kept phase with the light-dark cycle released larvae at different phases of the tidal and tidal amplitude cycles. This flexible timing system may increase mean reproductive success across tidal environments although survival of newly hatched larvae may vary.

The first 2 objectives of this study were to determine whether reproductive timing by fiddler crabs differed in diurnal, mixed semidiurnal and semidiurnal tidal regimes along the Gulf and Atlantic coasts of the USA and whether it also changed seasonally along the Gulf coast. The third objective was to determine whether the expected changes in reproductive timing were phenotypic. If reproductive timing by fiddler crabs is phenotypically plastic, then the degree of variation in the timing of larval release relative to several entrain- ing environmental cycles may indicate the relative dominance of rhythms controlling it. In either case, geographic and seasonal variation in reproductive timing may result in variable survival of newly hatched larvae across the range of fiddler crabs.

\section{METHODS AND MATERIALS}

Field sites. The timing of larval release by Uca pugilator was determined in adjacent diurnal and mixed semidiurnal tidal regimes along the northwestern coast of Florida during the summers of 1989 and 1990. Studies in a diurnal tidal environment were conducted at Presnell's Fish Camp, which is located on St. Joseph Bay (SJB), and studies in a mixed semidiurnal tidal environment were conducted $95 \mathrm{~km}$ away at Florida State University Marine Laboratory (FSU) at Turkey Point (Fig. 2).

Determining the timing of larval release in adjacent tidal regimes. The timing of larval release was determined from 15 to 28 April and from 19 May to 26 September at SJB and from 19 June to 24 September at FSU in 1989. Ovigerous (egg-bearing) females were dug from burrows near the high tide line; Uca panacea (Salmon) and other species of fiddler crabs carefully were excluded from collections. Ovigerous females were held individually in compartments $(4.5 \times 4 \times 4 \mathrm{~cm})$ of plastic trays at ambient seawater and light conditions. All ovigerous females were held in flowthrough seawater tables in an outdoor pavilion at FSU. Crabs were checked daily for larval release when seawater was changed, and ovigers were not fed.

This method yields accurate estimates of hatching patterns relative to lunar and tidal amplitude cycles as long as crabs are maintained at ambient conditions, because the date of larval release is determined once eggs are spawned. The date that ovigerous crabs are

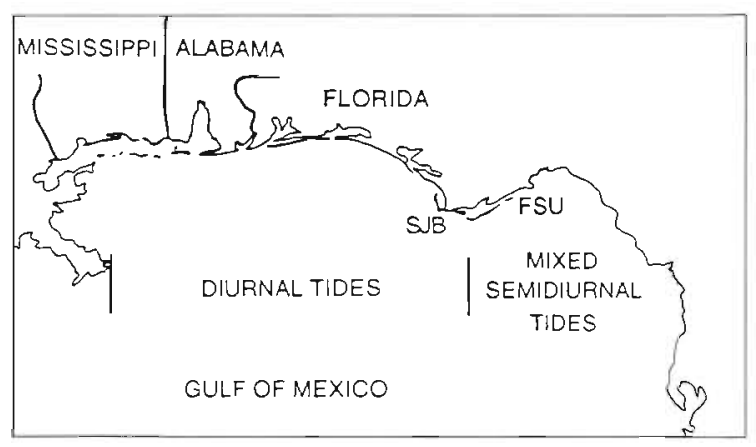

Fig. 2. Study sites in diurnal and mixed semidiurnal tidal regimes along the coast of northwestern Florida: St. Joseph Bay (SJB) and Florida State Marine Laboratory (FSU) at Turkey Point 
collected does not affect the timing of larval release as long as incubation periods are approximately $2 \mathrm{wk}$ long or larvae are released quite synchronously. This was confirmed here and in previous studies (DeCoursey 1983, Morgan \& Christy 1994, 1995) by comparing hatching patterns in trays to those determined in situ. Numbers of ovigerous females collected and collection dates are presented in Table 2 .

To determine whether crabs released larvae in darkness or light, trays were checked for larvae shortly after sunrise and before sunset until eggs of all females hatched. The timing of larval release relative to the tidal cycle was not determined by this method because this is best done in situ where tides reinforce rhythms (Morgan \& Christy 1994, 1995).

Translocation and field experiments. By July it had been established that reproductive timing by fiddler crabs differed at SJB and FSU, and crabs were translocated reciprocally between sites on 5 August to determine whether or not local rhythms would be entrained. Translocated crabs were held in pens that were $1.3 \mathrm{~m}$ high, $3 \mathrm{~m}$ wide and 6 or $11 \mathrm{~m}$ long. Pens extended from $1 \mathrm{~m}$ above the high tide line to $1 \mathrm{~m}$ below the low tide line. Pens were shorter at SJB because the shore was steeper than at FSU. Long pens were necessary, because most reproductively active fiddler crabs reside and release larvae near high water lines and forage throughout intertidal zones during low tides. Pens were constructed of $1.3 \mathrm{~m}$ rebar posts and $2.5 \mathrm{~cm}$ wire mesh. The wire mesh was covered with thick translucent sheets of plastic that extended from $0.5 \mathrm{~m}$ below ground to $1 \mathrm{~m}$ above ground to prevent crabs from entering or leaving pens by burrowing or climbing. A $15 \mathrm{~cm}$ strip of aluminum flashing surrounded the tops of pens to further ensure that crabs did not climb over the fence.

Pens were dug on 3 consecutive days beginning on 2 August to clear them of crabs. A total of 3425 $\left(190.3 \mathrm{~m}^{-2}\right)$ and $1210\left(36.7 \mathrm{~m}^{-2}\right)$ crabs were dug from pens at $\mathrm{SJB}$ and FSU, respectively, at a sex ratio of approximately 1:1 These crabs were held in drained outdoor seawater tanks at FSU. Sediment from each site was added to the bottom of tanks to allow these deposit-feeding crabs to feed and burrow. The flow of seawater through the tanks was adjusted to a trickle to keep the sediment moist. On the fourth day crabs were added to pens at a 1:1 sex ratio. All crabs that were dug from the pen at FSU were placed in the pen at SJB, and only about one-third of the crabs dug from SJB were added to the pen at FSU.

Two weeks after crabs were placed in pens, 100 ovigerous females were removed from each pen and 100 ovigers were dug from outside of the pens at each site (400 crabs total). Half of the crabs were held sepa-

Table 2. Uca pugilator. Timing of larval release ( $\mathrm{d} \pm 1 \mathrm{SD}$ ) relative to new and full moons (O) and tidal amplitudes in diurnal and mixed semidiurnal tidal regımes along the coast of NW Florida during 1989. Timing relative to maximum amplitude tides (MAT) and the largest amplitude high tides at night (NLAT) are reported for the diurnal and mixed semidiurnal tidal regimes, respectively. The time $(\mathrm{h})$ of predicted high tide on the date of peak hatching also is reported. Dawn occurred at approximately 06:00 $\mathrm{h}$ from May through July and at 06:30 h in August and September. Dates of biweekly sampling periods are given for determinıng timing of larval release relative to tidal amplitude, which cycles every $14 \mathrm{~d}$, and dates differ slightly for the lunar cycle, which has a $15 \mathrm{~d}$ periodicity. All values of Rayleigh's $r$-statistic were highly significant $\left(p<0.001\right.$ ), except where ${ }^{\cdots} p<0.01$ or ${ }^{n s} p>0.05$

\begin{tabular}{|c|c|c|c|c|c|c|c|c|c|}
\hline $\begin{array}{c}\text { Tidal regime } \\
\text { Date }\end{array}$ & Lunar & SD & $r$ & $\mathrm{n}$ & Tidal amplitude & $S D$ & $r$ & $\mathrm{n}$ & High tide \\
\hline \multicolumn{10}{|l|}{ Diurnal } \\
\hline $15 \mathrm{Apr}-28 \mathrm{Apr}$ & 0 & 3.0 & $0.22^{\mathrm{ns}}$ & 30 & $4<$ MAT & 2.8 & $0.23^{\mathrm{ns}}$ & 28 & $11: 19$ \\
\hline 19 May-1 Jun & $2<0$ & 2.5 & 0.46 & 76 & $5<\mathrm{MAT}$ & 2.4 & 0.42 & 75 & $08: 19$ \\
\hline 5 Jun-18 Jun & $4<0$ & 2.7 & 0.35 & 92 & $1<\mathrm{MAT}$ & 2.6 & 0.31 & 94 & $08: 18$ \\
\hline 19 Jun-2 Jul & $4<0$ & 2.9 & 0.28 & 101 & $6<$ MAT & 2.6 & 0.30 & 98 & $08: 35$ \\
\hline $3 \mathrm{Jul}-16 \mathrm{Jul}$ & $6<0$ & 1.8 & 0.73 & 63 & MAT & 1.8 & 0.68 & 66 & $06: 27$ \\
\hline 19 Jul-1 Aug & $4<0$ & 2.2 & 0.56 & 95 & $2<\mathrm{MAT}$ & 2.1 & 0.55 & 95 & $09: 24$ \\
\hline 2 Aug-15 Aug & $5<0$ & 1.6 & 0.78 & 42 & $2<\mathrm{MAT}$ & 15 & 0.77 & 41 & $07: 07$ \\
\hline 16 Aug-29 Aug & $6<0$ & 2.3 & 0.53 & 58 & $4<\mathrm{MAT}$ & 2.2 & 0.53 & 54 & $06: 01$ \\
\hline $30 \mathrm{Aug}-12$ Sep & $0<6$ & 2.2 & 0.56 & 91 & $2<\mathrm{MAT}$ & 2.1 & 0.57 & 88 & 02:05 \\
\hline $13 \mathrm{Sep}-26 \mathrm{Sep}$ & $0<4$ & 2.1 & 0.61 & 62 & $2<\mathrm{MAI}$ & 2.3 & 0.47 & 70 & $01: 15$ \\
\hline \multicolumn{10}{|l|}{ Mixed semidiurnal } \\
\hline 19 Jun-2 Jul & $0<3$ & 2.5 & 0.43 & 62 & NLAT & 2.3 & 0.62 & 60 & $05: 22$ \\
\hline $3 \mathrm{JuI}-16 \mathrm{Jul}$ & $O<4$ & 2.4 & 0.50 & 74 & NLAT $<1$ & 2.2 & 0.51 & 69 & $05: 15$ \\
\hline $17 \mathrm{Jul}-30 \mathrm{Jul}$ & $O<5$ & 2.7 & 0.44 & 116 & NLAT & 2.5 & 0.38 & 121 & $04: 50$ \\
\hline 31 Jul-13 Aug & 0 & 3.1 & $0.14^{\mathrm{ns}}$ & 64 & $2<$ NLAT & 2.5 & $0.38^{*}$ & 36 & $05: 33$ \\
\hline 14 Aug-27 Aug & $0<3$ & 3.1 & $0.18 \cdots$ & 153 & $1<$ NLAT & 2.9 & $0.18^{\mathrm{ns}}$ & 54 & $04: 31$ \\
\hline 28 Aug-10 Sep & $0<3$ & 2.7 & 0.34 & 92 & NLAT $<1$ & 2.7 & 0.29 & 102 & $03: 43$ \\
\hline 11 Sep-24 Sep & $0<3$ & 1.8 & 0.72 & 31 & NLAT $<2$ & 2.5 & 0.38 & 60 & $03: 03$ \\
\hline
\end{tabular}


rately in trays in the laboratory as described above. Following the methods of Morgan \& Christy (1994, 1995), the remaining crabs were placed inside 4 bottomless rectangular wooden boxes $(100 \times 50 \times 40 \mathrm{~cm})$ that were buried $24 \mathrm{~cm}$ deep and anchored in the midintertidal zone, where they were inundated daily by high tides. Local and translocated crabs were isolated in 2 boxes at each site. The walls and clear Plexiglas lids of boxes were perforated and screened with $153 \mu \mathrm{m}$ mesh Nitex cloth. An $18 \mathrm{~m}$ pump hose $(3.8 \mathrm{~cm}$ inner diameter) was connected to one end of each box. The opposite end of these hoses were attached to manual diaphragm pumps (approximately 4 I stroke $e^{-1}$ ) that were positioned above the high tide line at both sites. Each pump discharged through a hose into a $10 \mathrm{~cm}$ diameter plankton net (153 $\mu \mathrm{m}$ mesh) that was mounted in a holding tank. Newly hatched larvae were collected by pumping enough seawater through the screened openings to replace the seawater inside the tank and suction hose several times over (100 strokes). Immediately thereafter, hoses were disconnected from pumps, and those hoses attached to the second boxes were connected to pumps, and the pumping process resumed at each site. Collections were taken from both sets of boxes every 30 min, beginning when seawater covered the suction hoses and ending when the suction hoses were exposed again. A tidal gauge located by the boxes was used to measure tidal height every 30 min during a pumping cycle.

The timing of larval release by local and translocated crabs at each site was determined concurrently for $2 \mathrm{wk}$ until all females released larvae. Then 80 to 100 more ovigerous females, depending on availability, were dug biweekly from each pen and surrounding natural populations to replace crabs in boxes twice more during the next 4 wk. Crabs were replaced biweekly because the incubation period of Uca pugilator is about 13 to $14 \mathrm{~d}$, and all crabs release larvae by this time.

The amount of larvae released by crabs during each 30 min period at SJB was measured volumetrically in graduated test tubes. This technique could not be used for samples obtained from FSU because samples were contaminated with detritus. Instead the number of larvae was determined by counting larvae in aliquots beneath a dissecting microscope.

In late September, the pen at SJB was reinforced with $0.6 \mathrm{~cm}$ Vexar mesh and new plastic sheeting so that the integrity of the translocated population would be maintained until the following spring. The timing of larval release by translocated crabs and the surrounding population was determined for $2 \mathrm{wk}$ beginning on 3 June 1990 by holding crabs in trays as described above. The pen was disturbed after $2 \mathrm{wk}$, which allowed crabs to enter the pen, and the experiment was discontinued.
Data analysis. Data were divided into 14 and $15 \mathrm{~d}$ periods, because tidal amplitude cycles with the declination of the moon twice each tropical month $(27.32 \mathrm{~d})$ and new and full moons occur each lunar month $(29.53$ d). Rayleigh's $r$-statistic was used to detect peaks in timing of larval release relative to lunar and tidal amplitude cycles (Batschelet 1981). This test is appropriate for analysis of biological rhythms when periods of cycles are predetermined. The test compared the magnitude of the $r$-statistic, which is a measure of the temporal concentration of release times ranging from 0 to 1 , to that expected if crabs released larvae uniformly during a given physical cycle. If the $r$ statistic was significantly large, then the mean angle and angular deviation of the distribution identified the peak time and dispersion of larval release (reported as $\pm 1 \mathrm{SD}$ in Tables 2 to 5 ). Biweekly tests were conducted to determine whether reproductive timing changed during the reproductive season. The timing of larval release changed geographically and seasonally relative to the lunar cycle, suggesting that the moon did not entrain biweekly rhythms of reproduction. Therefore, the timing of larval release was reported relative to the tidal amplitude rather than the lunar cycle during translocation experiments. The $G$-test determined whether more females released larvae during the day or at night (Sokal \& Rohlf 1981).

The Watson-Williams test determined whether reproductive timing by crabs taken from natural populations differed in diurnal and mixed semidiurnal tidal regimes (Batschelet 1981). The number of days separating the time of peak larval release from maximum amplitude tides and new and full moons in these tidal regimes indicated whether larval release was better synchronized with the tidal amplitude or lunar cycle. The $G$-test determined whether the number of females releasing larvae during daylight and darkness differed between tidal regimes (Sokal \& Rohlf 1981). These 2 tests were also used to detect differences in reproductive timing by translocated and local crabs.

\section{RESULTS}

\section{Timing of larval release in two tidal regimes}

The timing of larval release by UCa pugilator differed in diurnal and mixed semidiurnal tidal regimes. Biweekly peaks of larval release in the diurnal tidal regime corresponded with minimal release in the mixed semidiurnal tidal regime (Fig. 3). In the diurnal tidal regime, larval release relative to lunar and tidal amplitude cycles was asynchronous in April, early in the reproductive season as has been described previously in other tidal regimes (Wheeler 1978, Christy 


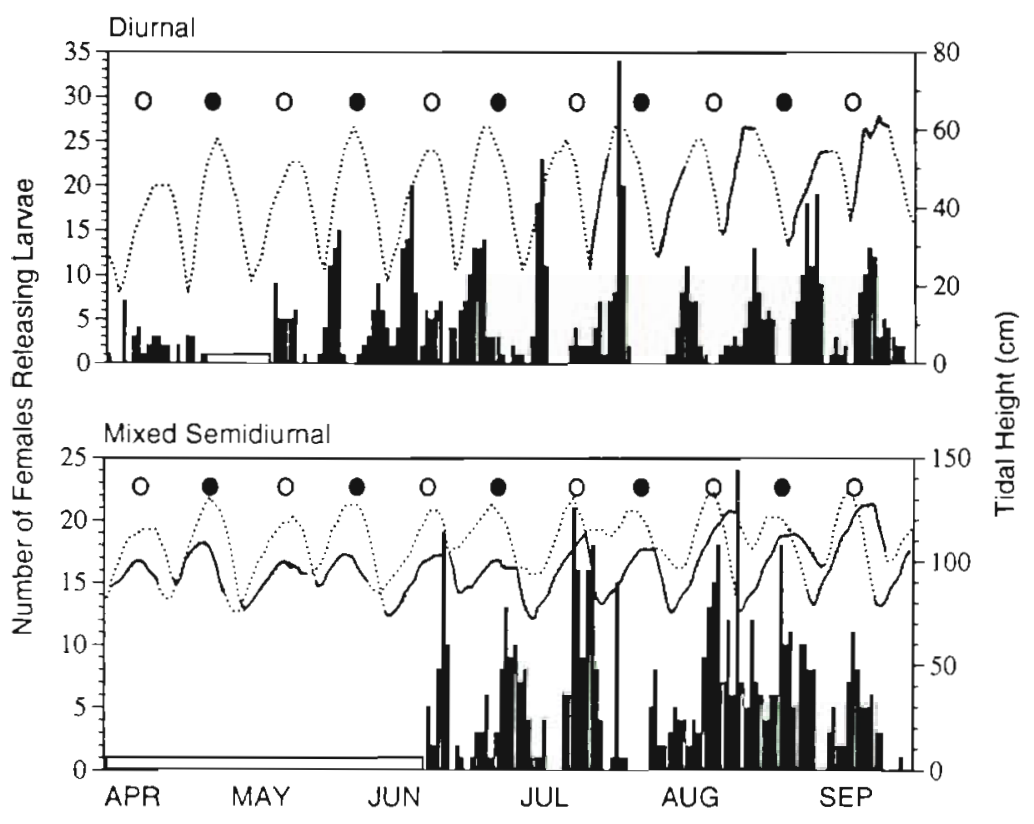

Fig. 3. Uca pugilator. Number of crabs releasing larvae relative to predicted lunar and tidal amplitude cycles in diumal and mixed semidiumal tidal regimes along the coast of northwestern Florida in 1989. Sampling was conducted from 15 to 28 April and from 19 May to 26 September in the diurnal tidal regime and from 19 June to 24 September in the mixed semidiurnal tidal regime. See Table 2 for sample sizes and collection dates. Symbols as in Fig. 1. Shaded areas indicate no data

1982). Thereafter, biweekly peaks in larval release generally occurred several days before maximum amplitude tides during tides of intermediate amplitude (Table 2) Peak larval release relative to lunar phase changed during the reproductive season. Early in the reproductive season, most females released larvae several days before new and full moons, and by the end of the season peak larval release occurred several days after new and full moons. The timing of larval release relative to the light-dark cycle also would have changed during the reproductive season, assuming that females released larvae near high tide as they do on the Atlantic coast. To release larvae on high tide, females would have released larvae about $2 \mathrm{~h}$ after dawn from May through July, and thereafter they would have released larvae progressively earlier in the day. In August, peak larval release would have occurred within 30 min of dawn, and in September it would have occurred 1 to $2 \mathrm{~h}$ after midnight.

In contrast to the timing of larval release in the diurnal tidal regime, females in the mixed semidiurnal tidal regime released larvae several days after maximum amplitude tides (Fig 3, Table 2). The largest amplitude nocturnal high tides occurred at this time. Peak larval release relative to the lunar cycle also differed in the mixed semidiurnal tidal regime, where it generally occurred 3 to $5 \mathrm{~d}$ after new and full moons. The timing of larval release relative to lunar phase did not change as much during the reproductive season as it did in the diurnal tidal regime, in which the study period was longer and hatching was more synchronous (see also 'Reciprocal translocation experiments'). Larval release relative to lunar and tidal amplitude cycles became less synchronous in August. The timing of peak larval release relative to the light-dark cycle also would have differed between the 2 tidal regimes during July and August when peak larval release would have occurred on high tides shortly before dawn at the mixed semidiurnal site. A seasonal shift likely occurred in September when peak larval release would have occurred earlier at night, as was observed in the diurnal tidal regime.

Despite differences in the timing of larval release in the 2 tidal regimes, the percentage of larvae released during daytime and nighttime was similar $(G=$ $0.78 ; \mathrm{df}=1,2 ; \mathrm{p}>0.05)_{i}$ most females released larvae at night in both tidal regimes. In the diurnal tidal regime, $93 \%$ of females released larvae at night, and $88 \%$ of females released larvae at night in the mixed semidiurnal tidal regime. This is consistent with the predicted timing of larval release relative to high tide in the mixed semidiurnal tidal regime, in which most females would have released larvae on high tides before dawn (Table 2). It also is consistent with the predicted timing of larval release relative to high tide in the diurnal tidal regime from mid-August through September, when high tides also occurred before dawn. However, it is not consistent with larval release earlier in the reproductive season when peak larval release would have occurred on high tides after dawn at the diurnal site. This suggests that larval release occurred during late flood tides in darkmess rather than near high slack tide in daylight.

\section{Reciprocal translocation experiments}

Intraspecific differences in the timing of larval release by crabs in the 2 tidal regimes may be induced environmentally. In the laboratory, the timing of peak larval release by crabs that were translocated from the mixed semidiurnal to the diurnal tidal regime differed from that of local crabs for as long as 6 wk after translocation (Fig. 4, Table 3). However, the timing of larval release 
was very similar between local and translocated crabs by the following year, clearly showing that crabs eventually entrained local hatching rhythms. Furthermore, the timing of peak larval release by crabs that were translocated from the diurnal to the mixed semidiurnal tidal regime was similar within 2 mo of translocation.

In the field, the timing of peak larval release by local and translocated crabs at the diurnal site was more alike than it was for crabs held in the laboratory, suggesting that tidal rhythms were still being entrained after crabs were collected (Fig 5, Table 4). Biweekly peaks in larval release occurred only $1 \mathrm{~d}$ apart throughout the study period. Furthermore, the distributions were not significantly different during 2 of the 3 biweekly periods. The timing of larval release relative to high tide initially differed by less than 30 min during the $24.8 \mathrm{~h}$ tidal cycle (Fig. 6, Table 4). By the end of the experiment, translocated crabs released larvae 1 h after high tide as did local crabs, while lacal crabs in the mixed semidiurnal tidal regime released larvae at high tide throughout the study period (Table 5). However, the distribution of larval release over the lengthy tidal cycle differed throughout the study period. The timing of larval release relative to the light-dark cycle was similar by translocated and local crabs, although the time of day that translocated and local crabs released larvae differed by $1 \mathrm{~h}$ throughout the study period (Fig 7 , Table 4). Both translocated and local crabs released larvae in darkness shortly before dawn, but peak larval release by translocated crabs occurred 1 h earlier in the day than by local crabs. Local females released $69 \%$ of larvae before dawn (06:30 h), $80.3 \%$ of larvae were released by $07: 00 \mathrm{~h}$ and $98.1 \%$ were released by $08: 30 \mathrm{~h}$. Translocated females released $85.7 \%$ of larvae before dawn, $91.2 \%$ were released by $07: 00 \mathrm{~h}$ and $96 \%$ were released by $08: 30 \mathrm{~h}$.

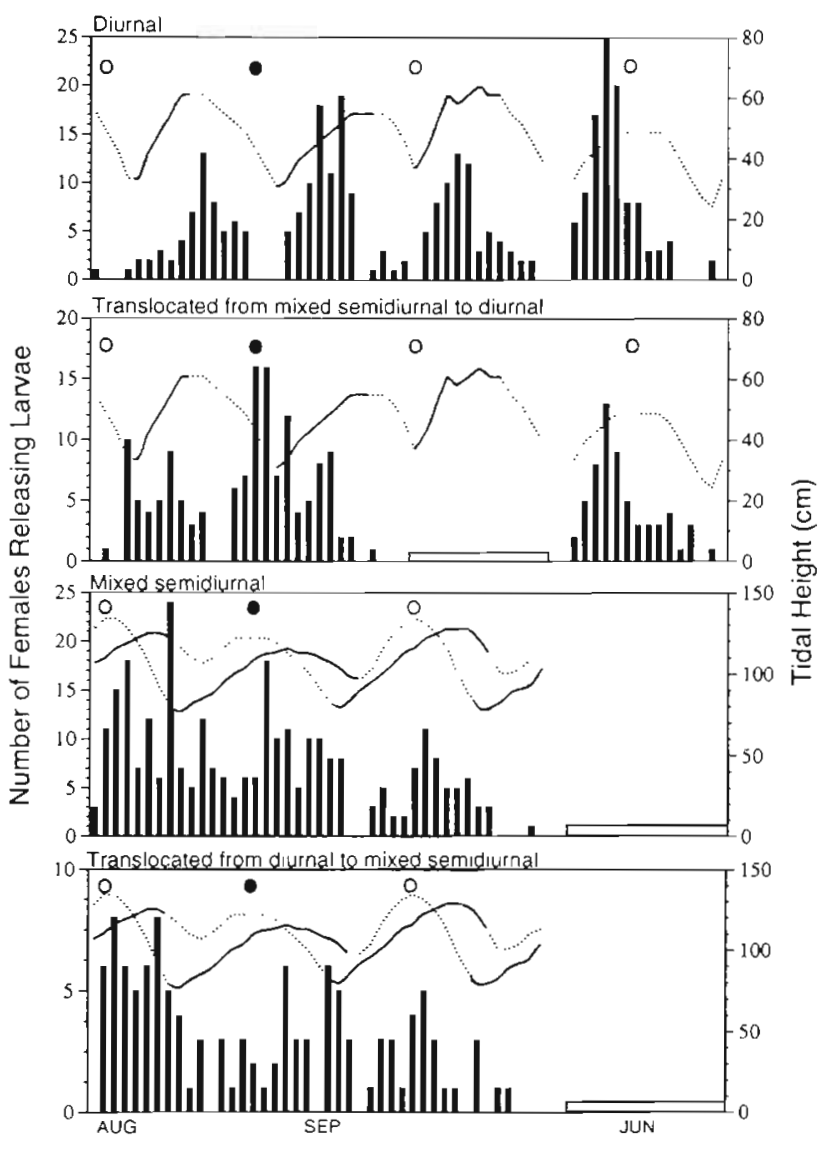

Fig. 4. Uca pugilator. Number of local and translocated crabs releasing larvae relative to predicted lunar and tidal amplitude cycles in the laboratory. Ovigerous females were collected from a diurnal tidal regime at St. Joseph Bay and a mixed semidiurnal tidal regime at the Florida State Marine Laboratory the coast of northwestern Flonda and were translocated reciprocally between sites on 5 August 1989. See Table 3 for sample sizes. Shaded areas indicate no data. See Figs. $1 \& 3$ for other symbols

Table 3. Uca pugilator. Timing of larval release $(\mathrm{d} \pm 1 \mathrm{SD})$ by local and translocated crabs relative to tidal amplitude cycles in the laboratory. Crabs were collected from a diurnal tidal regime near St. Joseph Bay and a mixed semidiurnal tidal regime at the Florida State Marine Laboratory and were translocated reciprocally between sites on 5 August 1989. Larval release relative to maximum amplitude high tide (MAT) is reported from 17 August to 12 September 1989 and from 3 to 16 June 1990 for crabs at the diurnal site, and relative to amplitude high tides at night (NLAT) from 16 August to 26 September 1989 for crabs from the mixed semidiurnal site. All values of Rayleigh's $r$-statistic are significantly different $(p<0.05\}$, except where indicated by ${ }^{n}$ ' Watson-Williams' $F$-statistic tested for significant differences ( $\left.p<0.05 ; \cdots p<0.01_{i} \cdots p<0.001\right)$ in the timing of larval release in the 2 tidal regimes

\begin{tabular}{|c|c|c|c|c|c|c|c|c|c|c|}
\hline \multirow[t]{2}{*}{ Tidal regime } & \multirow[t]{2}{*}{ Date } & \multicolumn{4}{|c|}{ Diurnal crabs } & \multicolumn{5}{|c|}{ Mixed semidiurnal crabs } \\
\hline & & Timing & $\mathrm{SD}$ & $\mathrm{n}$ & $r$ & Timing & $\mathrm{SD}$ & $n$ & $r$ & $F$ \\
\hline \multirow[t]{3}{*}{ Diurnal } & 17 Aug 1989 & MAT & 2.2 & 54 & 0.53 & $5<$ MAT & 2.5 & 52 & 0.35 & $52.75 \cdots$ \\
\hline & 28 Aug 1989 & $3<\mathrm{MAT}$ & 2.1 & 88 & 0.57 & $7<\mathrm{MAT}$ & 2.5 & 91 & 0.37 & $131.60^{\cdots} \cdot$ \\
\hline & 3 Jun 1990 & $2<M A T$ & 2.2 & 105 & 0.62 & $2<M A T$ & 2.7 & 59 & 0.48 & 0.60 \\
\hline \multirow{3}{*}{$\begin{array}{l}\text { Mixed } \\
\text { semidiurnal }\end{array}$} & 17 Aug 1989 & $1<$ NLAT & 2.5 & 56 & 0.37 & $1<$ NLAT & 2.9 & 137 & $0.18^{\mathrm{ns}}$ & 2.67 \\
\hline & 28 Aug 1989 & NLAT $<2$ & 2.9 & 38 & $0.16^{\text {ns }}$ & $1<$ NLAT & 2.6 & 100 & 0.31 & $5.46^{\circ}$ \\
\hline & 11 Sep 1989 & $2<$ NLAT & 2.4 & 23 & 0.42 & $1<\mathrm{NLAT}$ & 2.2 & 53 & 0.53 & 2.76 \\
\hline
\end{tabular}




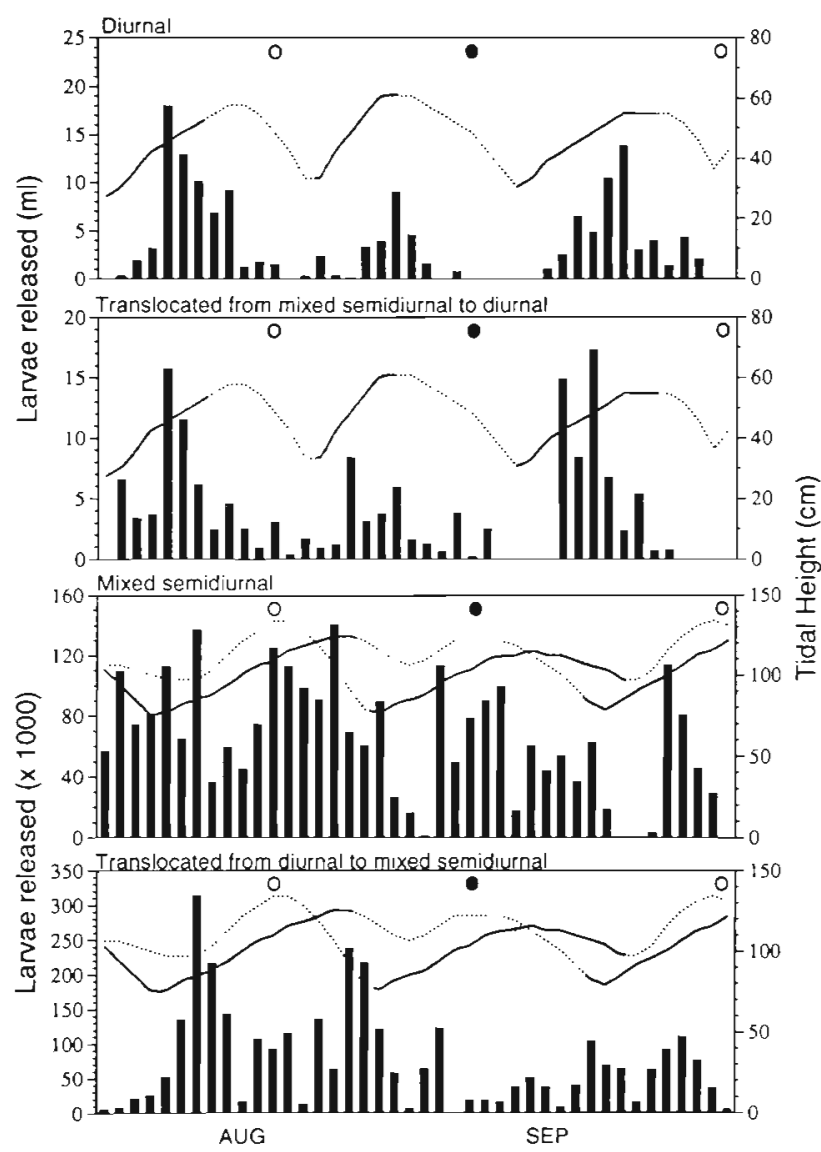

Fig. 5. Uca pugilator. Volume or number of larvae released by local and translocated crabs relative to lunar and tidal amplitude cycles in the field from 6 August to 16 September 1989. Ovigerous females were collected from a diurnal tidal regime at St. Joseph Bay and a mixed semidiurnal tidal regime at the Florida State Marne Laboratory along the coast of northwestern Florida and were translocated reciprocally between sites on 5 August 1989. 140 crabs were sampled during the 6 wh period. See Figs. 1 \& 3 for symbols

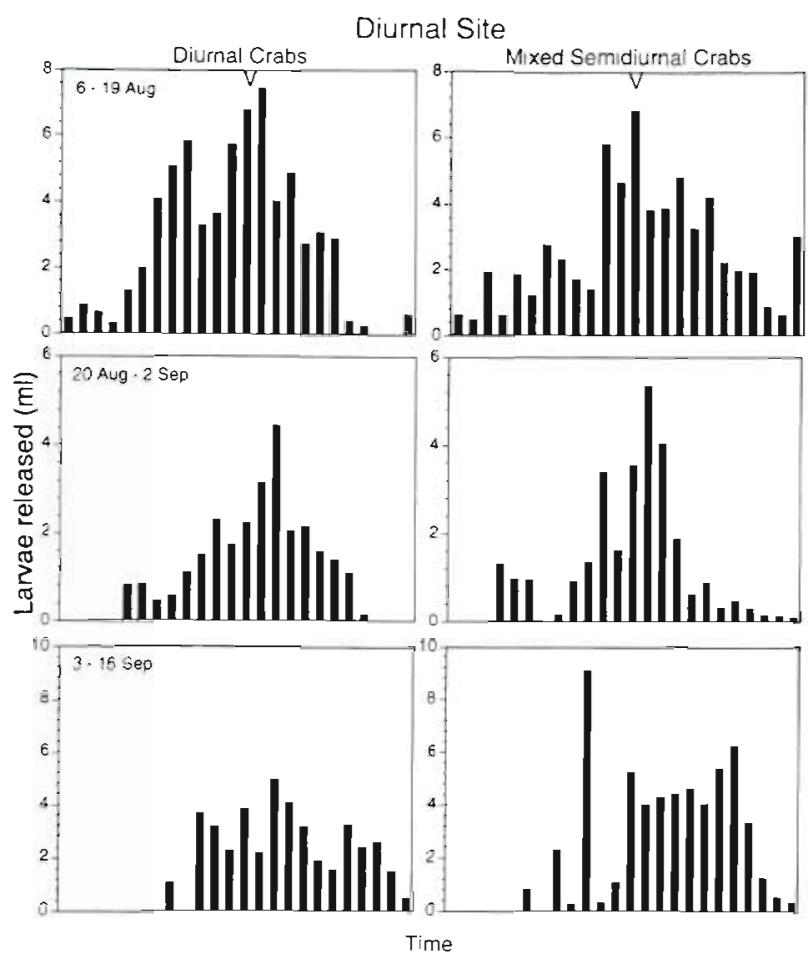

Fig. 6. Uca pugilator. Volume of larvae released every $30 \mathrm{~min}$ by local and translocated crabs relative to high tide (inverted triangle) in a diurnal tidal regime on the coast of northwestern Florida from 6 August to 16 September 1989. Ovigerous females were collected from a mixed semidiurnal tidal regime at the Florida State Marine Laboratory and were translocated to the diurnal tidal regime at St. Joseph Bay on 5 August 1989 140 crabs were sampled during the 6 wk period. See Figs. $1 \&$ 3 for symbols

Table 4. Uca pugilator. Timing of larval release by local and translocated crabs relatuve to tidal amplitude, tidal and light-dark cycles for 6 wk 6 August to 16 September 1989 ) in a diurnal tidal regime near St. Joseph Bay. Translocated crabs were collected from a mixed semidiurnal tidal regime at Florida State Marine Laboratory. Fifty local and translocated crabs each were sampled during the first 2 biweekly periods, and 40 were sampled during the third period. Larval release relative to maximum amplitude high tides (d from MAT $\pm 1 \mathrm{SD}$ ), high slack tide ( $\mathrm{h}$ from $\mathrm{HT} \pm 1 \mathrm{SD}$ ) and time of day (h $\pm 1 \mathrm{SD}$ ) is reported. Dawn occurred about 06:30. All values of Rayleigh's $r$-statistic are highly significantly different ( $p<0.001$ ). Watson-Williams' F-statistic tested for significant differences ( " $p<0.01 ., " p<0.001)$ in the timing of larval release in the 2 tidal regimes

\begin{tabular}{|c|c|c|c|c|c|c|c|c|}
\hline \multicolumn{2}{|c|}{ Diurnal site } & \multicolumn{3}{|c|}{ Diurnal crabs (local) } & \multicolumn{4}{|c|}{ Mixed semidiurnal crabs (translocated) } \\
\hline Cycle & Date & Timing & $\mathrm{SD}$ & $r$ & Timing & $\mathrm{SD}$ & r & $F$ \\
\hline $\begin{array}{l}\text { Tidal } \\
\text { amplitude }\end{array}$ & $\begin{array}{r}6 \text { Aug } \\
20 \text { Aug } \\
3 \text { Sep }\end{array}$ & $\begin{array}{r}3<\text { MAT } \\
\text { MAT } \\
1<\text { MAT }\end{array}$ & $\begin{array}{l}1.9 \\
2.0 \\
2.8\end{array}$ & $\begin{array}{l}0.64 \\
0.59 \\
0.53\end{array}$ & $\begin{array}{l}4<\mathrm{MAT} \\
1<\mathrm{MAT} \\
2<\mathrm{MAT}\end{array}$ & $\begin{array}{l}2.3 \\
2.5 \\
1.9\end{array}$ & $\begin{array}{l}0.48 \\
0.37 \\
0.61\end{array}$ & $\begin{array}{c}3.65 \\
30.01 \cdots \\
2.85\end{array}$ \\
\hline Tidal & $\begin{array}{r}6 \text { Aug } \\
20 \text { Aug } \\
3 \text { Sep }\end{array}$ & $\begin{array}{l}0.5<\mathrm{HT} \\
\mathrm{HT}<0.5 \\
\mathrm{HT}<1\end{array}$ & $\begin{array}{l}1.9 \\
2.8 \\
2.0\end{array}$ & $\begin{array}{l}0.51 \\
0.57 \\
0.44\end{array}$ & $\begin{array}{c}H T \\
H T \\
H T<1\end{array}$ & $\begin{array}{l}2.2 \\
1.9 \\
1.9\end{array}$ & $\begin{array}{l}0.35 \\
0.54 \\
0.50\end{array}$ & $\begin{array}{c}10.71 \cdots \\
43.05 \cdots \\
9.61 \cdots\end{array}$ \\
\hline Light-dark & $\begin{array}{r}6 \text { Aug } \\
20 \text { Aug } \\
3 \text { Sep }\end{array}$ & $\begin{array}{l}05: 30 \\
05: 00 \\
04: 30\end{array}$ & $\begin{array}{l}2.1 \\
3.1 \\
3.1\end{array}$ & $\begin{array}{l}0.85 \\
0.67 \\
0.67\end{array}$ & $\begin{array}{l}04: 30 \\
04: 30 \\
03: 30\end{array}$ & $\begin{array}{l}2.7 \\
2.9 \\
2.6\end{array}$ & $\begin{array}{l}0.75 \\
0.71 \\
0.78\end{array}$ & $\begin{array}{r}143.60 \cdots \\
53.33 \cdots \\
107.78 \cdots\end{array}$ \\
\hline
\end{tabular}


At the mixed semidiurnal site, the timing of larval release by local crabs in the field was asynchronous throughout the study period (Fig. 5, Table 5). Translocated crabs released larvae quite synchronously during the first biweekly period, but they also released larvae asynchronously by the end of the experiment. Furthermore, peak larval release by translocated crabs changed from occurring 7 d after large amplitude nocturnal high tides to occurring near these tides, when most local females released larvae (Table 5). As with the tidal amplitude cycle, the timing of larval release by translocated and local crabs relative to the tidal cycle became increasingly similar (Fig. 8, Table 5). Local females released most larvae during high tide throughout the study period, but translocated females initially released larvae $1 \mathrm{~h}$ before high tide. By the end of the experiment, larval release by translocated females peaked during high slack tides and was not significantly different from that of local females. As in the diurnal tidal regime, larval release by local and translocated crabs relative to the light-dark cycle did not differ, but the exact hour of the day that most females released larvae remained significantly different throughout the experiment (Fig. 9, Table 5). Peak larval release by crabs from both tidal regimes initially occurred soon after dawn in daylight and later occurred several hours before dawn in darkness. Local females released $61.7 \%$ of larvae before dawn $(06: 30 \mathrm{~h}), 75.2 \%$ of larvae were released by $08: 00 \mathrm{~h}$ and $83.3 \%$ were released by 10:00 h. Translocated females released $66.6 \%$ of larvae before dawn, $72.9 \%$ were released by $08: 00 \mathrm{~h}$ and $92.7 \%$ were released by $10: 00 \mathrm{~h}$.

\section{DISCUSSION}

\section{Spatial and temporal variation in reproductive timing}

Reproductive timing by fiddler crabs on the Gulf and Atlantic coasts differed, and it differed for populations that were only $95 \mathrm{~km}$ apart on the Gulf coast (Table 6).

\section{Diurnal Site}
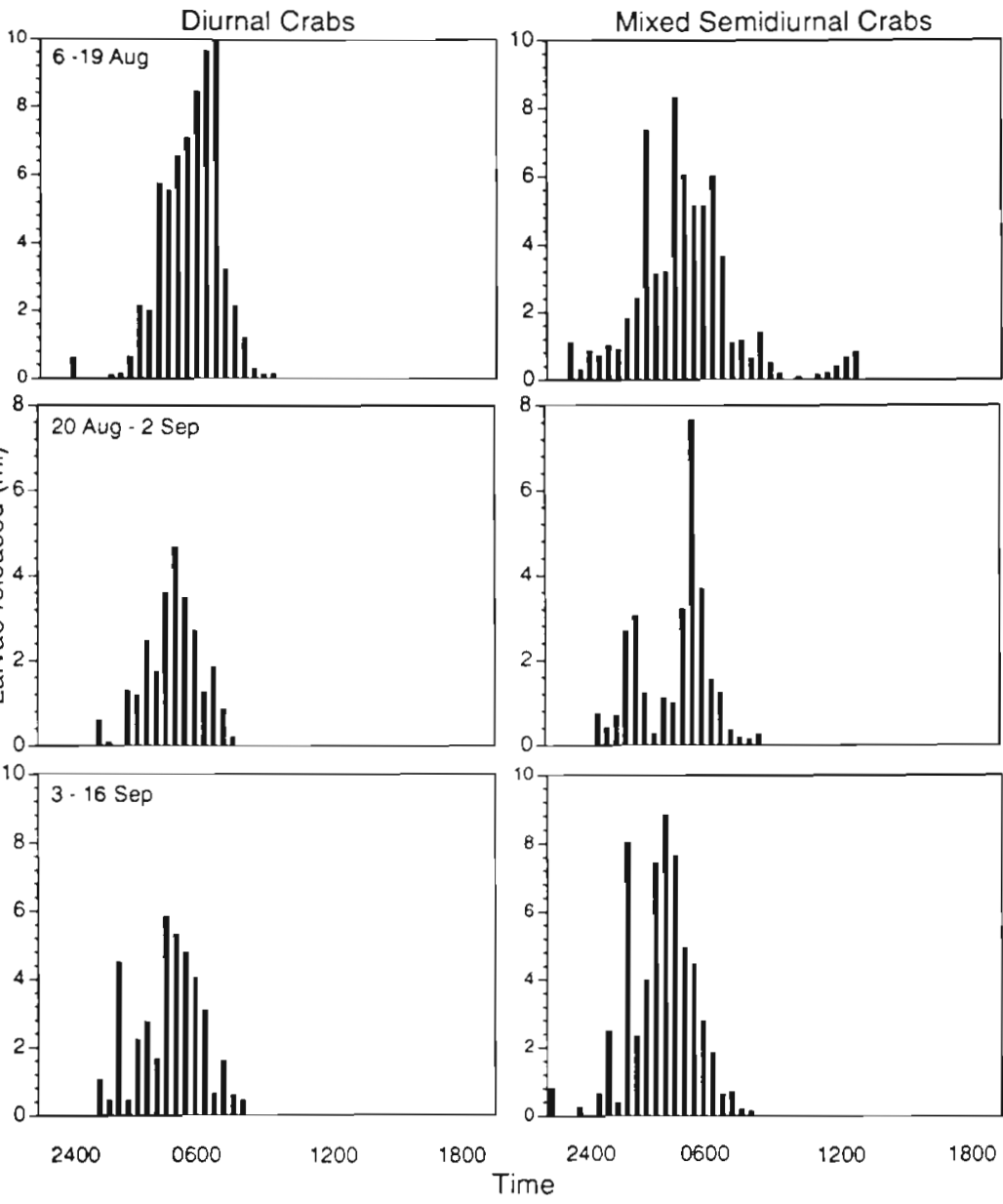

Fig. 7 Uca pugilator. Volume of larvae released every $30 \mathrm{~min}$ by local and translocated crabs relative to the light-dark cycle (hour of the day) in a diurnal tidal regime on the coast of northwestern Florida from 6 August to 16 September 1989. Ovigerous females were collected from a mixed semidiurnal tidal regime at the Florida State Marine Laboratory and were translocated to the diurnal tidal regime at St. Joseph Bay on 5 August 1989. 140 crabs were sampled during the 6 wk perıod. Dawn occurred at about 06:30 h. See Figs. 1 \& 3 for symbols

The timing of larval release changed relative to all 4 entraining environmental cycles between the Atlantic and Gulf coasts, and it changed relative to 3 of the 4 cycles in the 2 Gulf coast populations. Intraspecific variation in reproductive timing most likely arose because the phase relationships of entraining environmental cycles differed over the range of the species. Although lunar and light-dark cycles occurred at similar times in all 3 tidal regimes, the timing of tides changed relative to these cycles. Because larval release was synchronized with the tides, the timing of larval release necessarily changed relative to lunar and light-dark cycles across tidal regimes.

Larvae were released only at night on the Atlantic coast, but about $10 \%$ of females from both Gulf coast sites released larvae during the daytime in the labora- 
Table 5. Uca pugilator. Timing of larval release relative to tidal amplitude, tidal and light-dark cycles by local and translocated crabs for 6 wk $(6$ August to 16 September 1989) in a mixed semidiurnal tidal regime at Florida State Marine Laboratory. Translocated crabs were collected from a diurnal tidal regime near St. Joseph Bay, Florida, in 1989. Fifty local and translocated crabs each were sampled during the first 2 biweekly periods, and 40 were sampled during the third period. Larval release relative to the largest amplitude high tides at night ( $d$ from NLAT \pm 1 SD), high slack tide (h from HT $\pm:$ SD) and time of day (h \pm 1 SD) is reported. Dawn occurred about 06:30 h. All values of Rayleigh's $r$-statistic are highly significantly different ( $p<0.001)$, except where indicated by ${ }^{n s}$ Watson-Williams' F-statistic tested for significant differences $(\cdot p<0.05, \cdots p<0.01, \cdots p<0.001)$ in the tıming of larval release in the 2 tidal regimes

\begin{tabular}{|c|c|c|c|c|c|c|c|c|}
\hline \multicolumn{2}{|c|}{ Mixed site } & \multicolumn{3}{|c|}{ Mixed semidiurnal crabs (local) } & \multicolumn{4}{|c|}{ Diurnal crab (translocated) } \\
\hline Cycle & Date & Timing & $\mathrm{SD}$ & r & Timing & $\mathrm{SD}$ & $r$ & $F$ \\
\hline $\begin{array}{l}\text { Tidal } \\
\text { amplitude }\end{array}$ & $\begin{array}{r}6 \text { Aug } \\
20 \text { Aug } \\
3 \text { Sep }\end{array}$ & $\begin{aligned} & \text { NLAT } \\
& 1<\text { NLAT } \\
& 3<\text { NLAT }\end{aligned}$ & $\begin{array}{l}3.0 \\
2.9 \\
2.9\end{array}$ & $\begin{array}{l}0.07^{\mathrm{ns}} \\
0.18^{\mathrm{ns}} \\
0.17^{\mathrm{ns}}\end{array}$ & $\begin{array}{l}\text { NLAT }<7 \\
\text { NLAT }<2 \\
2<\text { NLAT }\end{array}$ & $\begin{array}{l}2.3 \\
2.3 \\
2.9\end{array}$ & $\begin{array}{l}0.49 \\
0.45 \\
0.17^{\text {ns }}\end{array}$ & $\begin{array}{c}14.50^{\cdots} \\
9.95^{\circ} \\
6.03^{\circ}\end{array}$ \\
\hline Tidal & $\begin{array}{r}6 \text { Aug } \\
20 \text { Aug } \\
3 \text { Sep }\end{array}$ & $\begin{array}{l}\mathrm{HT} \\
\mathrm{HT} \\
\mathrm{HT}\end{array}$ & $\begin{array}{l}1.5 \\
1.5 \\
1.2\end{array}$ & $\begin{array}{l}0.62 \\
0.63 \\
0.75\end{array}$ & $\begin{aligned} & 1<\mathrm{HT} \\
& 0.5<\mathrm{HT} \\
& \mathrm{HT}\end{aligned}$ & $\begin{array}{l}0.9 \\
0.9 \\
0.8\end{array}$ & $\begin{array}{l}0.43 \\
0.45 \\
0.62\end{array}$ & $\begin{array}{c}20.32 \cdots \\
29.88 \cdots \\
1.11\end{array}$ \\
\hline Light-dark & $\begin{array}{c}6 \text { Aug } \\
20 \text { Aug } \\
3 \text { Sep }\end{array}$ & $\begin{array}{l}07: 00 \\
02: 00 \\
03: 00\end{array}$ & $\begin{array}{l}3.2 \\
4.0 \\
3.9\end{array}$ & $\begin{array}{l}0.65 \\
0.47 \\
0.48\end{array}$ & $\begin{array}{l}07: 30 \\
04: 00 \\
03: 00\end{array}$ & $\begin{array}{l}2.6 \\
2.2 \\
2.7\end{array}$ & $\begin{array}{l}0.78 \\
0.84 \\
0.75\end{array}$ & $\begin{array}{r}8.41 \cdots \\
18.81 \cdots \\
22.41 \cdots\end{array}$ \\
\hline
\end{tabular}

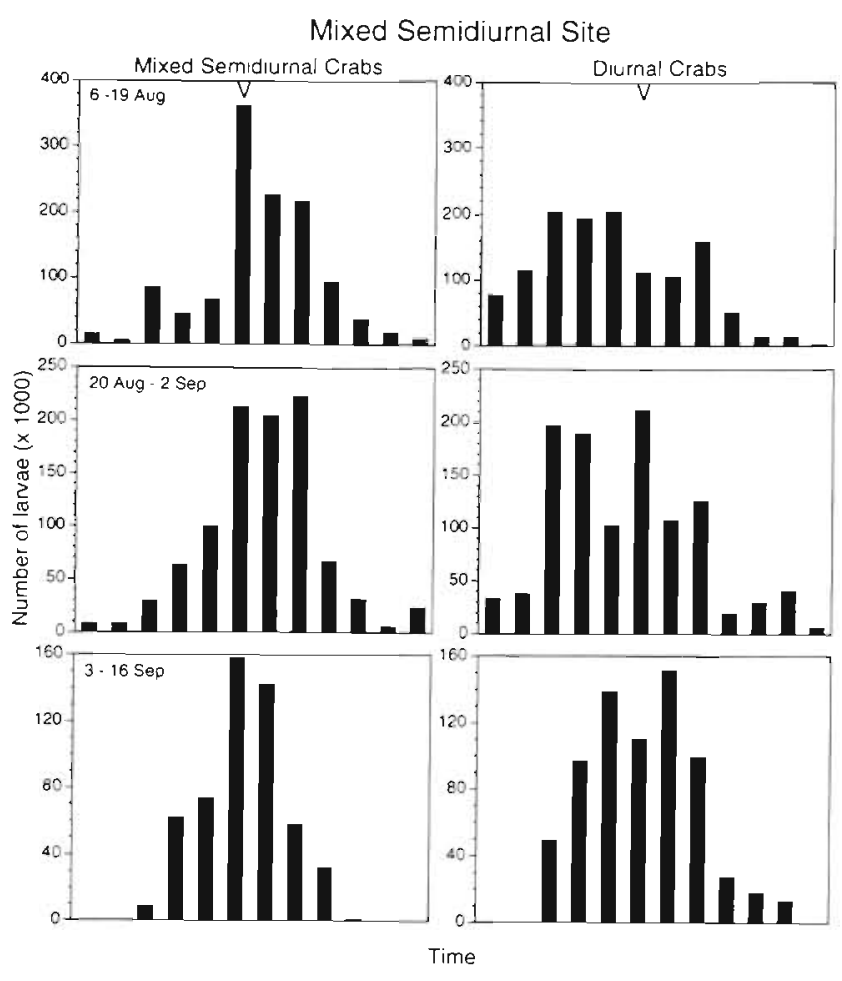

Fig. 8. Uca pugilator. Number of larvae released every $30 \mathrm{~min}$ by local and translocated crabs relative to high tide (inverted triangle) in a mixed semidiurnal tidal regime on the coast of northwestern Florida from 6 August to 16 September 1989 Ovigerous females were collected from a diurnal tidal regime at St. Joseph Bay and were translocated to the mixed semidiurnal tidal regime at the Florida State Marine Laboratory on 5 August 1989. 140 crabs were sampled during the $6 \mathrm{wk}$ period See Figs. $1 \& 3$ for symbols tory and in natural populations (S. Morgan \& S. McAfee unpubl.). The greater proportion of larvae released during the daytime in field experiments probably was an artifact of experimental design. Breeding populations along the Gulf coast largely live above the tide line, and most females must walk to the waterline to release larvae before returning to burrows by dawn. By holding crabs lower on the shore, ovigerous females were inundated by tides and the high turbidity at both sites would have reduced light intensities at the bottom. This likely extended larval release by these crabs beyond dawn in both tidal regimes. Water was more turbid at the mixed semidiurnal than the diurnal site, causing more larvae to be released during daylight.

By releasing larvae mostly at night, Gulf coast females could not also release larvae during maximum amplitude high slack tides as they do on the Atlantic coast. Reproductive timing relative to either the tidal amplitude or tidal cycles had to change. Reproductive timing relative to the tidal amplitude cycle changed in both diurnal and mixed semidiurnal tidal regimes along the Gulf coast where peak larval release occurred during intermediate amplitude tides. The timing of larval release did not change relative to the tidal cycle at the mixed semidiurnal site where intermediate amplitude high slack tides occurred at night. However, at the diurnal site, high slack tides occurred soon after dawn during intermediate amplitude tides, requiring larval release in darkness to occur 1 to $2 \mathrm{~h}$ before high slack tide (Table 2). In the field experiment, most females did release larvae on nocturnal flood tides in early August, when maximum amplitude high tides still occurred in daylight, and naturally 
occurring females also commonly released larvae during flood tides before dawn (Morgan \& McAfee unpubl.). For larval release to peak during nocturnal high slack tides from April to July, females would have had to release larvae on $1 \mathrm{~d}$ during minimum amplitude tides (Fig 1). Peak release on intermediate flood tides may be favored over highly synchronous release during minimum amplitude high slack tides, because high tides persist for $12 \mathrm{~h}$ and are low in amplitude. Consequently, tidal height would diminish only slightly if larvae were released during late flood tides, and it would be even greater during intermediate amplitude tides. Thus, peak larval release was synchronized throughout most of the season with nocturnal intermediate amplitude flood tides in the diurnal tidal regime and nocturnal intermediate amplitude high slack tides in the mixed semidiurnal tidal regime.

Biweekly periodicity in reproduction by fiddler crabs clearly was not entrained by the lunar cycle. Geographic differences in reproductive timing occurred relative to the lunar cycle even though the same phase of the moon occurred concurrently in all 3 tidal regimes (Table 6). Females typically released larvae during new and full moons on the Atlantic coast, before new and full moons at the diurnal site, and after new and full moons at the mixed semidiurnal site from mid-June through September. In a previous month-long study, fiddler crabs in a mixed semidiurnal tidal regime along the coast of northwestern Florida released larvae dur-
Mixed Semidiurnal Site

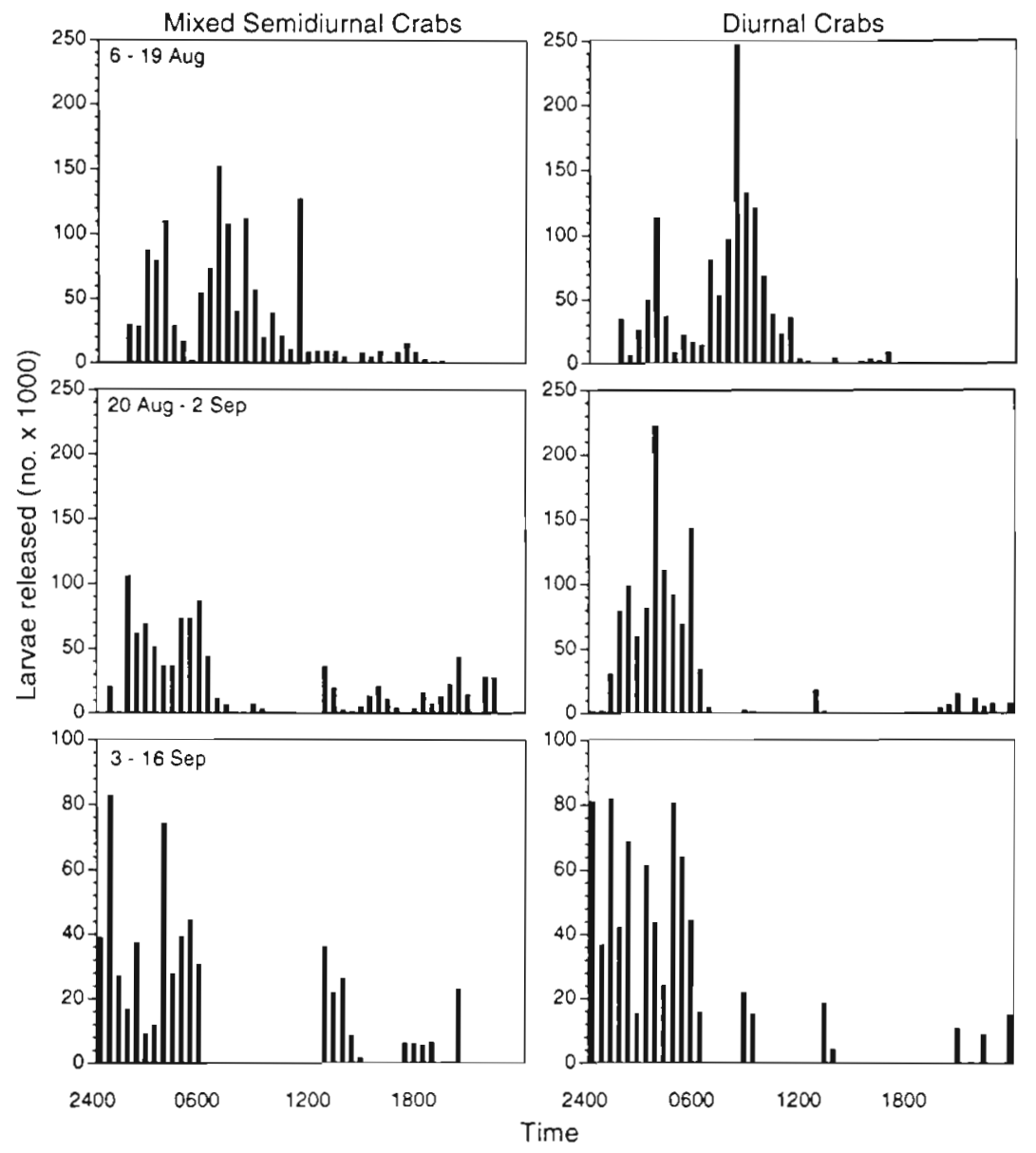

Fig. 9. UCa pugilator. Number of larvae released every 30 min by local and translocated crabs relative to the light-dark cycle (hour of the day) in a mixed semidiurnal tidal regime on the coast of northwestern Florida from 6 August to 16 September 1989. Ovigerous females were collected from a diurnal tidal regime at St. Joseph Bay and were translocated to the mixed semidiurnal tidal regime at the Florida State Marine Laboratory on 5 August 1989. 140 crabs were sampled during the 6 wk period. Dawn occurred at about 6:30 h. See Figs. 1 \& 3 for symbols

Table 6. Uca pugilator. Summary of reproductive timing relative to 4 environmental cycles in 3 tidal regumes along the Atlantic and Gulf coasts of the USA. The timing of larval release in the semidiurnal tidal regime was determined previously (DeCoursey 1979, Bergin 1981, Christy 1982, Salmon et al. 1986, Morgan 1990, Hovel 1995). High: high slack and early ebb tide

\begin{tabular}{|c|c|c|c|c|}
\hline \multirow{2}{*}{ Tidal regime } & \multicolumn{4}{|c|}{ Environmental cycle } \\
\hline & Lunar & Tidal amplitude & Tidal & Light-dark \\
\hline Semidiurnal & New and full & Maximum & High & $\begin{array}{l}\text { Evening } \\
\text { (dark only) }\end{array}$ \\
\hline Mixed semidiurnal & Asynchronous & $\begin{array}{c}\text { Intermediate } \\
\text { (before maximum) }\end{array}$ & High & $\begin{array}{c}\text { Dawn } \\
\text { (dark mostly) }\end{array}$ \\
\hline Diurnal & Asynchronous & $\begin{array}{c}\text { Intermediate } \\
\text { (after maximum) }\end{array}$ & Flood or high & $\begin{array}{c}\text { Dawn } \\
\text { (dark mostly) }\end{array}$ \\
\hline
\end{tabular}


and full moons from April through September, while it usually occurred before maximum amplitude tides throughout the reproductive season. The tidal amplitude rather than the lunar cycle has entrained reproductive rhythms by all but one species of crab tested (Saigusa 1988, Morgan \& Christy 1994, Morgan 1995, 1996) and by Gulf coast killifish, Fundulus grandis (Hsiao \& Meier 1989).

Reproductive timing by fiddlers crabs is similar throughout the summer on the Atlantic coast, where the phasing of entraining environmental cycles changes little. However, the timing of larval release appeared to change during the reproductive season in the diurnal tidal regime. In mid-August, nocturnal maximum amplitude high tides returned, thereby enabling females to release larvae on these tides as they do on the Atlantic coast (Table 6). Evidence of a temporal shift in reproductive timing relative to the tidal amplitude cycle was not clearly indicated by crabs that were held in the laboratory, but it was suggested by crabs that were studied in the field. In early August, females in the field released larvae several days before maximum amplitude tides, as they did earlier in the season in the laboratory, but from late August through early September, peak larval release occurred 0 to $1 \mathrm{~d}$ before maximum amplitude tides as expected. At the same time, larval release shifted from late flood to early ebb tides. Furthermore, fewer larvae were released in daylight late in the summer because large amplitude high tides occurred near midnight rather than near dawn.

Temporal changes were not expected in the mixed semidiurnal tidal regime because nocturnal maximum amplitude high tides did not return before crabs ceased reproduction; intermediate amplitude high tides occurred at night throughout the reproductive season. Although larval release peaked on nocturnal high slack tides throughout the $6 \mathrm{wk}$ field study as expected, reproduction became poorly synchronized. relative to the tidal amplitude cycle late in the season for reasons that are not clear

\section{Hierarchies of rhythms regulating reproductive timing}

Reproductive timing by fiddler crabs is phenotypically plastic. The timing of larval release not only varied temporally within a single population, but translocated crabs entrained to the hatching patterns of local crabs. In both tidal regimes, reproductive timing by translocated crabs relative to tidal amplitude, tidal and light-dark cycles either did not differ significantly or closely matched that of local crabs when the $6 \mathrm{wk}$ experiment concluded.
This plasticity suggests that hierarchies of endogenous rhythms determined the timing of larval release as originally proposed by Morgan \& Christy (1994). Reproductive timing by fiddler crabs was regulated by tidal amplitude, tidal and light-dark cycles, but the relative influence of the 3 cycles differed. These hierarchies were revealed by the degree to which larval release kept phase with each of the 3 environmental cycles. The light-dark cycle may be the dominant rhythm determining reproductive timing by fiddler crabs because females usually released larvae at night in all 3 tidal regimes. Larval release always occurred during high tide, but it sometimes occurred during late flood tide, enabling larvae to hatch in darkness at the diurnal site. Hence, the tidal cycle may be of secondary importance to the light-dark cycle. The tidal amplitude cycle may exert even less influence because larval release occurred on intermediate rather than maximum amplitude tides during most of the reproductive season in both tidal regimes. Thus, reproductive timing by fiddler crabs may be regulated by the phasing of 3 environmental cycles in order of decreasing influence: light-dark, tidal and tidal amplitude cycles.

Similar hierarchies of rhythms have been proposed for 3 other Gulf coast crabs (Sesarma cinereum, Panopeus simpsoni, Panopeus obesus) that share this reproductive timing pattern (Morgan 1996). Four other Gult coast crabs (Eurypanopeus depressus, Sesarma reticulatum, Dyspanopeus texana, Dissodactylus mellitae) released larvae near maximum amplitude high tides in broad daylight, even though larvae hatched in darkness on the Atlantic coast, suggesting that a different hierarchy of rhythms regulates reproductive timing by these crabs (Morgan 1996). Thus, the first group of Gulf coast species, including fiddler crabs, primarily release larvae at night, sometimes forsake releasing larvae on high slack tide and usually forsake releasing larvae on maximum amplitude tides. The second group of crabs release larvae on maximum amplitude high slack tides and forsake releasing larvae primarily at night.

\section{Optimality}

This flexible timing system apparently enables fiddler crabs to synchronize reproduction appropriately in several different tidal regimes (see Morgan 1995, Morgan \& Christy 1995 for reviews of the adaptive significance of reproductive timing). Larvae primarily are released at night in all 3 tidal environments and initially escape diurnally foraging planktivorous fishes (Hobson \& Chess 1978, Zaret 1980. Christy 1982, Lazarro 1987, Morgan 1990). Fiddler crab larvae in the 
3 tidal environments also are released near high slack tide and are swept by ebb tides from shorelines (Morgan 1990, Hovel 1995, Morgan \& McAfee unpubl.) where planktivorous fishes are particularly abundant (e.g. Weinstein 1979, Boesch \& Turner 1984, Sogard \& Able 1991, Ayvazian et al. 1992). The risk of predation would be reduced even further in all 3 tidal regimes, because larvae are released on intermediate to large amplitude tides that would transport them from shorelines even more effectively than if they were released during lower amplitude tides (Christy 1982, Christy \& Stancyk 1982, Salmon et al. 1986).

If this adaptive scenario is correct, then newly hatched larvae should survive well across the range of the species. Nevertheless, differences in reproductive timing in the 3 tidal environments did occur, and predation by dense assemblages of planktivorous fishes along shorelines was greater on the Gulf than the Atlantic coast (Morgan \& McAfee unpubl.). On the Atlantic coast, peak larval release occurred early in the evening, thereby maximizing the time for dispersal from shorelines and diffusion from offspring before dawn. However, on the Gulf coast, peak larval release usually occurred near dawn, minimizing the time for larval dispersal and diffusion, and about $10 \%$ of females even released larvae after dawn while planktivorous fishes were foraging. Furthermore, releasing larvae near maximum amplitude high slack tides would maximize transport of vulnerable larvae from shorelines on the Atlantic coast, and larval transport would be less effective on the Gulf coast where larvae are released during submaximal tides and tidal ranges generally are low (Table 1). Furthermore, larvae released during flood tide in the diurnal tidal regime initially would be carried shoreward into shallow marshes and tidal creeks, where they would encounter predatory benthic invertebrates and may be stranded during most of the reproductive season (Salmon et al. 1986, Morgan 1987, Morgan \& Christy 1994).

Temporal variation in initial reproductive success also may occur along the Gulf coast. Late in the reproductive season, fiddler crabs appeared to release larvae during maximum amplitude high tides at night as they did on the Atlantic coast, which may reduce larval predation rates. In the mixed semidiurnal tidal regime, predation rates may be increased late in the reproductive season when larval release is poorly synchronized with the tidal amplitude cycle. Because reproductive timing changes little in the semidiurnal tidal regime (see DeCoursey 1979, Bergin 1981, Christy 1982, Salmon et al. 1986, Morgan 1990, Hovel 1995), predation on newly hatched larvae should not vary, as long as other variables are held constant.

Regardless of whether predation or another selective factor ultimately determines the reproductive periodic- ities of fiddler crabs, intraspecific variation in reproductive timing will result in variable mortality of newly hatched larvae even though mean reproductive success may be enhanced by endogenous hierarchies of rhythms. This timing system may have arisen because fiddler crab larvae commonly disperse $30 \mathrm{~km}$ from shore on both the Atlantic and Gulf coasts, before they reinvade estuaries as postlarvae (Truesdale \& Andryszak 1983, Epifanio et al. 1988, Matthews 1995, Schell 1996). Consequently, offspring may settle and reproduce in tidal environments that differ from that of the parents. The parental reproductive timing pattern would increase mortality of newly hatched larvae in the new tidal environment, where it would not be synchronized with local environmental cycles. Thus, a flexible timing system would be favored over a genetically predetermined timing pattern, and gene flow in these widely dispersing organisms may prevent local adaptation to different tidal regimes.

Thus, reproductive timing by fiddler crabs differed relative to lunar, tidal amplitude, tidal and light-dark cycles in 3 tidal regimes along the Atlantic and Gulf coasts, and temporal variation also was observed in the 2 Gulf coast tidal regimes. This variation is phenotypic and may be caused by tidal variation. The changing phase relationships of the tides with light-dark and lunar cycles necessarily produced variation in tidally timed activities. Peak larval release by females kept phase with light-dark, tidal, tidal amplitude cycles in order of decreasing flexibility, suggesting that a hierarchy of rhythms regulated reproductive timing. Reproduction by fiddler crabs did not track the lunar cycle This ranking of rhythms ensured that most larvae were released during nocturnal high slack tides of at least intermediate amplitude, which may reduce predation on newly hatched larvae across the range of the species. However, differences in tidally timed reproduction by fiddler crabs in the 3 tidal environments necessarily arose, and survival of newly hatched larvae may vary among tidal regimes.

Acknowledgements. I thank Jack Hitron for facilitating research at the Florida State University Marme Laboratory Skyli McAfee provided logistical support and assisted with all phases of the project. Steve Bray, Randy Coggin, Wendy Neally, Tami Lambert, Marshall Connelly, Felix Fernandez. Mario Tamburri, Laurie Sulluvan assisted with field work Sandra Sumrall and Alma Robicheux assisted with sample processing. Michael Salmon provided computer programs for analyzing data by circular statistics and commented on the manuscript. John Christy and Michael Salmon provided helpful comments on the experimental design. I thank George Crozler and Bob Shipp for their support and encouragement during the study. This research was supported by NSF grant (NSFR11-8996152-90-012), a grant from the Coastal Research and Development Institute of the University of South Alabama, and a postdoctoral fellowship from the Marine Environmental Sciences Consortium. 


\section{LITERATURE CITED}

Ayvazian SG, Deegan LA, Finn JT (1992) Comparison of habitat use by estuarine fish assemblages in the Acadian and Virginian zoogeographic provinces. Estuaries 15 : $368-383$

Barnwell, FH (1976) Variation in the form of the tide and some problems it poses for biological timing systems. In: DeCoursey PJ (ed) Biological rhythms in the marine environment. Belle W. Baruch Library in Manne Science Num. ber 4. University of South Carolina, Columbia, South Carolına, p 161-187

Batschelet E (1981) Circular statistics in biology. Academic Press, New York

Bergin ME (1981) Hatching rhythms in UCa pugilator (Decapoda: Brachyura). Mar Biol 63:151-158

Boesch DF, Turner RE (1984) Dependence of fishery species on salt marshes: the role of food and refuge. Estuaries 7: $460-468$

Christy JH (1978) Adaptive significance of reproductive cycles in the fiddler crab Uca pugilator a hypothesis. Science 199:453-456

Christy JH (1982) Adaptive significance of semilunar cycles of larval release in fiddler crabs (Genus Uca): test of an hypothesis. Biol Bull 163:251-263

Christy JH. Stancyk SE (1982) Movement of larvae from North Inlet estuary, SC with special reference to crab zoeae. In: Kennedy V (ed) Estuarine comparisons. Academic Press, New York, p 489-501.

DeCoursey PJ (1979) Egg hatching rhythms in three species of fiddler crabs. In: Naylor E, Hartnoll RG (eds) Cyclic phenomena in marine plants and animals. Proceedings of the 13th European Marine Biological Symposium, Pergamon, Oxford, p 399-406

DeCoursey PJ (1983) Biological timing. In: Bliss DE (ed) The biology of Crustacea, Vol 7 Academic, New York, $p$ $107-161$

Epifanio CE, Little KE, Rowe PM (1988) Dispersal and recruitment of fiddler crab larvae in the Delaware River estuary. Mar Ecol Prog Ser 43:181-188

Forward RB Jr (1987) Larval release rhythms of decapod crustaceans: an overview. Bull Mar Sci 41:165-176

Gibson RN (1978) Lunar and tidal rhythms in fish. In: Thorpe JE (ed) Rhythmic activity of fishes. Academic Press, New York, p 201-213

Giese AC, Kanatani H (1987) Maturation and spawning. In: Giese AC, Pearse JS, Pearse VB (eds) Reproduction of marine invertebrates, Vol 9. Blackwell Scientific Press, Palo Alto, p $251-329$

Hobson ES, Chess JR (1978) Trophic relationships among fishes and plankton in the lagoon at Enewetok atoll, Marshall Islands. Fish Bull 76:133-153

Hovel K (1995) Predation and photodamage selecting for rapid transport of crab larvae through a salt marsh. MSc thesis, State University of New York, Stony Brook

Hsiao SM, Meier AH (1989) Comparison of semilunar cycles of spawning activity in Fundulus grandis and $F$. heterocli-

This article was presented by J. Pawlik, Wilmington, North Carolina, USA tus held under constant laboratory conditions. J Exp Zool 252:213-218

Lazarro X (1987) A review of planktivorous fishes: their evolution, feeding behaviors, selectivities and impacts. Hydrobiologia 146:97-167

Matthews A (1995) Cross-shelf transport of decapod larvae in New York Bight. MSc thesis. State University of New York, Stony Brook

Morgan SG (1987) Adaptive significance of hatching rhythms and dispersal patterns of estuarine crab larvae: avoidance of physiological stress by larval export? J Exp Mar Biol Ecol 113:71-78

Morgan SG (1990) lmpact of planktivorous fishes on dispersal, hatching, and morphology of estuarine crab larvae. Ecology 71:1639-1652

Morgan SG (1995) The timing of larval release. In: McEdward $L$ (ed) The ecology of marine invertebrate larvae. CRC Press, Boca Raton, FL, p 157-191

Morgan SG (1996) Influence of tidal variation on reproductive timing. J Exp Mar Biol Ecol (in press)

Morgan SG, Christy JH (1994) Plasticity, constraint and optimality in reproductive timing. Ecology 75:2185-2203

Morgan SG, Christy JH (1995) Adaptive significance of the timing of larval release by crabs. Am Nat 145:457-479

Neumann D (1966) Die lunare und tägliche Schlüpfperiodik der Mücke Clunio. Z Vergl Physiol 53:1-61

Neumann D (1986) Life cycle strategies of an intertidal midge between subtropical and Arctic latitudes. In: Taylor F. Karban $\mathrm{R}$ (eds) The evolution of insect life cycles. SpringerVerlag, New York, p 3-19

Palmer JD (1974) Biological clocks in marine organisms. John Wiley and Sons, London

Palmer JD (1990) The rhythmic lives of crabs. BioSci 40: $352-358$

Saigusa M (1988) Entrainment of tidal and semilunar rhythms by artificial moonlight cycles. Biol Bull 174:126-138

Salmon M. Seiple WH, Morgan SG (1986) Hatching rhythms of fiddler crabs and associated species at Beaufort, North Carolina. J Crust Biol 6:24-36

Schell J (1996) Variation in the timing of verticai swimming by crab larvae and megalopae between tidal regimes. MSc thesis, State University of New York, Stony Brook

Sogard SM, Able KW (1991) A comparison of eelgrass, sea lettuce macroalgae, and marsh creeks as habitats for epibenthic fishes and decapods. Estuar Coast Shelf Sci 33: $501-519$

Sokal RR, Rohlf FJ (1981) Biometry. WH Freeman, San FranCisco

Truesdale FM. Andryszak BL (1983) Occurrence and distribution of reptant decapod crustacean larvae in neritic Louisiana waters: July 1976. Contr Mar Sci 26:37-53

Weinstein MP (1979) Shallow marsh habitats as primary nurseries for fishes and shellfish, Cape Fear River, North Carolina. Fish Bull 77:339-356

Wheeler DE (1978) Semilunar hatching periodicity in the mud fiddler crab Uca pugnax (Smith). Estuaries 1:268-269

Zaret TM (1980) Predation and freshwater communities. Yale University, New Haven, CT

Manuscript first received: November 14, 1995

Revised version accepted: March 19, 1996 